\title{
Mioepitelioma benigno: presentación de un caso clínico
}

\section{Benign myoepithelioma: presentation of a case report}

\author{
A. Ostrosky', D.M. Villa², M. González², F. Klurfan²
}

Resumen: Se presenta un caso de mioepitelioma benigno de glándula parótida, el cual fue tratado mediante la lobectomía superficial de la glándula, con conservación del nervio facial. Se hace el diagnóstico diferencial con otros tumores benignos como el adenoma pleomorfo, con el cual comparten una clínica similar. También se destaca la importancia de un correcto diagnóstico anatomopatológico, en este caso haciendo diagnóstico diferencial con los carcinomas epi-mioepiteliales.

Palabras clave: Mioepitelioma benigno; Tumores parótida.

Recibido: 18.04 .06

Aceptado: 06.10 .06

\begin{abstract}
We present a case of benign myoepithelioma of the parotid gland, which was treated by superficial gland lobectomy along with facial nerve conservation. A differential diagnosis with other benign tumors with similar clinical signs such as pleomorphic adenoma is made. The importance of a correct anatomopathologic diagnosis is also stressed, as is making a differential diagnosis with epi-myoepithelial carcinomas.
\end{abstract}

Key words: Benign myoepithelioma; Parotid tumors.

\footnotetext{
1 Jefe del Servicio de Cirugía Maxilofacial.

2 Concurrente del Servicio de Cirugía Maxilofacial.

Hospital Mariano y Luciano de la Vega. Moreno, Argentina
}

\section{Correspondencia:}

Alejandro Otrosky

Arenales 1578- José C. Paz.

Buenos Aires, Argentina.

Email: diegomartinvilla@hotmail.com 


\section{Introducción}

Existen muchas controversias en cuanto a la clasificación de los tumores mioepiteliales o de células claras. Se pueden distinguir dos variedades de mioepitelioma, la benigna y la maligna. El término carcinoma epi-mioepitelial es introducido por Donath en 1972 y aceptado por la OMS, y se refiere a otra entidad patológica diferente que puede ser confundida con el mioepitelioma.

El mioepitelioma benigno es un tumor poco frecuente de glándulas salivales, representando aproximadamente el $1 \%$ del total de estos tumores. ${ }^{1}$ Es encapsulado y tiene un crecimiento lento, casi siempre asintomático. Afecta un amplio rango de edades, siendo la media los 40 años. Afecta en un $48 \%$ la glándula parótida, en un $10 \%$ la submaxilar y en un $42 \%$ las glándulas menores. ${ }^{2,3}$

Histológicamente, el mioepitelioma benigno está compuesto por células mioepiteliales. Se acepta la presencia de hasta 5\% de células epiteliales ductales como normal, mientras que un mayor número de formaciones ductales orienta hacia el diagnóstico de un tumor mixto. Se distinguen 5 patrones celulares en el mioepitelioma benigno: 1) células fusimormes, 2) células plasmocitoides, 3) patrón reticular, 4) células claras, y 5) combinación de varios tipos.2,3 El índice de recurrencia de este tipo de tumor es bajo cuando se lo extirpa totalmente.

El mioepitelioma maligno presenta similitudes y diferencias con la variedad benigna ya descrita. Es un tumor de mediano a alto grado de malignidad. Se presenta principalmente en la glándula parótida (65\%). Histológicamente presenta células mioepiteliales, pero se observa atipia celular e infiltración neural y de estructuras vecinas. Pueden existir metástasis a distancia y tiende a recidivar en un $60 \%$ de los casos. ${ }^{2,3}$

El carcinoma epi-mioepitelial es un tumor maligno de bajo grado. En contraste a los miepiteliomas, presenta una estructura histológica tubular bifásica. ${ }^{4-6}$ Presenta una capa interna formada por células ductales epiteliales, y una capa externa de células mioepiteliales claras. Puede haber una cápsula incompleta. Batsakis (1992) clasifica a este carcinoma en 3 subtipos: 1) con predominio de células mioepiteliales claras sin formación de ductos, 2) de células mioepiteliales fusimormes, y 3) con predominio de células ductales epiteliales. Otros clasifican al mismo tumor en 2 variedades, una tubular, con las dos capas de células visibles, y otra sólida con predominio de células claras mioepiteliales. Se observan pocas atipias celulares y un bajo índice mitótico, ${ }^{7}$ aunque suele invadir nervios y vasos vecinos. Su crecimiento es lento, en general asintomático, aunque puede general dolor en la región del nervio facial si invade los nervios. Se presenta mayormente en mujeres de la $7^{\mathrm{a}}$ década de vida, y aparece en un $80 \%$ en la glándula parótida. Se han reportado metástasis a distancia en un $10 \%$ de casos y adenopatías regionales en un $20 \%$. El índice de recurrencias va del $20 \%$ al $50 \%$, y en general el curso de la enfermedad es prolongado debido a las recidivas. ${ }^{4}$

El mioepitelioma benigno debe ser extirpado siguiendo los límites del tumor. ${ }^{3}$ Si la resección es completa las recurrencias son raras.

El mioepitelioma maligno debe ser resecado con amplios márgenes de seguridad, seguido por radioterapia. ${ }^{3}$

Con respecto al carcinoma epi-mioepitelial, el tratamiento de elección es la resección del tumor con amplios márgenes. Varios

\section{Introduction}

There is much controversy as to the classification of myoepithelial or clear cell tumors. Two varieties can be distinguished, benign and malignant. The term epi-myoepithelial carcinoma was introduced by Donath in 1972 and accepted by the WHO, and it refers to a different pathological entity that can be confused with myoepithelioma.

Benign myoepithelioma is an uncommon tumor of the salivary glands, representing approximately $1 \%$ of the total of these tumors. ${ }^{1}$ It is encapsulated and slow-growing, and it is nearly always asymptomatic. It affects a wide age range, and the mean age is 40. The parotid gland is affected $48 \%$ of the time, the submaxillary glands $10 \%$ and minor glands $42 \% .^{2-3}$

Histologically, benign myoepithelioma is composed of myoepithelial cells. The presence of up to $5 \%$ of ductal epithelial cells is considered normal, while a large number of ductal formations will guide us towards a mixed tumor diagnosis. Five cellular patterns can be distinguished in benign myoepithelioma: 1) spindle cells, 2) plasmocytoid cells, 3) reticular pattern, 4) clear cells, and 5) combination of various types. ${ }^{2-3}$ The rate of recurrence of this type of tumor is low when completely excised.

Malignant myoepithelioma has similarities and differences with the benign variety that has been described. It has medium-to-high grade malignancy. It arises principally in the parotid gland (65\%). Histologically it has myoepithelial cells, but cellular atypia is observed together with neural infiltration and infiltration of neighboring structures. There may be distant metastasis and there is a tendency for recurrence in $60 \%$ of cases. $^{2-3}$

Epi-myoepithelial carcinoma is a low-grade malignant tumor. In contrast with myoepithelioma it has a biphasic tubular histological structure. ${ }^{4-6}$ It has an internal layer made up of epithelial ductal cells, and an external layer of clear myoepithelial cells. The capsule may be incomplete. Batsakis (1992) classified this carcinoma into three subtypes: 1) with a predominance of clear myoepithelial cells, 2) with spindle shaped myoepithelial cells, and 3) with a predominance of ductal epithelial cell. Others classify the same tumor in two varieties, one tubular with two visible layers of cells and another solid with a predominance of clear myoepithelial cells. There is little cellular atypia and there is a low mitotic rate, 7 although neighboring nerves and vessels tend to be invaded. It is slow-growing and generally asymptomatic although there may be general pain the region of the facial nerve, if the nerves are invaded. It appears generally in women in the 7th decade of life and $80 \%$ of the time it appears in the parotid gland. In 10\% of cases distant metastasis has been reported and regional adenopathy in $20 \%$. The rate of recurrence is between $20 \%$ and $50 \%$ and in general the course of the disease is prolonged due to recurrence. ${ }^{4}$

Benign myoepithelioma should be removed along the tumor borders. ${ }^{3}$ If it is completely resected recurrence is rare. 
autores aconsejan la radioterapia en los tumores con diámetro mayor a $4 \mathrm{~cm}$, aunque se demostró que es un tumor poco radiosensible. ${ }^{4}$

\section{Caso clínico}

Paciente de sexo femenino, de 67 años de edad, derivado al Servicio de Cirugía Maxilofacial de nuestro hospital, presentando una tumoración circunscripta en la región parotídea izquierda. A la palpación se presentaba con consistencia pastosa, fácilmente desplazable, sin signos de infección ni alteraciones de la piel. No encontramos adenopatías palpables en las cadenas ganglionares del cuello. No presentaba ningún tipo de dolor en la zona del tumor. Al examen intrabucal no se observaron alteraciones. El tiempo de evolución era de 3 años. La paciente no presentaba otras alteraciones sistémicas de relevancia (Fig. 1).

Se solicitó una tomografía computada, mediante la cual se observa que el tumor compromete el lóbulo superficial de la glándula parótida izquierda. No hay evidencia de alteraciones en los tejidos vecinos. Dada la clínica, el diagnóstico presuntivo es de un tumor benigno de glándulas salivales (Fig. 2).

Bajo anestesia general y a través de un abordaje extraoral, se procedió a la extirpación del tumor, realizando la lobectomía superficial de la glándula parótida con conservación del nervio facial (Figs. 3 y 4 ).

La anatomía patológica confirma el diagnóstico de mioepitelioma benigno. Los análisis inmunohistoquímicos revelan marcadores típicos para las células mioepiteliales claras: actina, proteína S100 y vimentina (Figs. 7, 8 y 9). ${ }^{8}$

El postoperatorio cursa sin complicaciones. Sólo se evidencia una paresia de los músculos peribucales en el lado operado, la cual remite totalmente a los 3 meses. Luego de un año de seguimiento no se detectan signos de recidiva (Figs. 5 y 6).

\section{Discusión}

Es de gran importancia el diagnóstico realizado por pátologos que tengan un amplio conocimiento en tumores de glán-

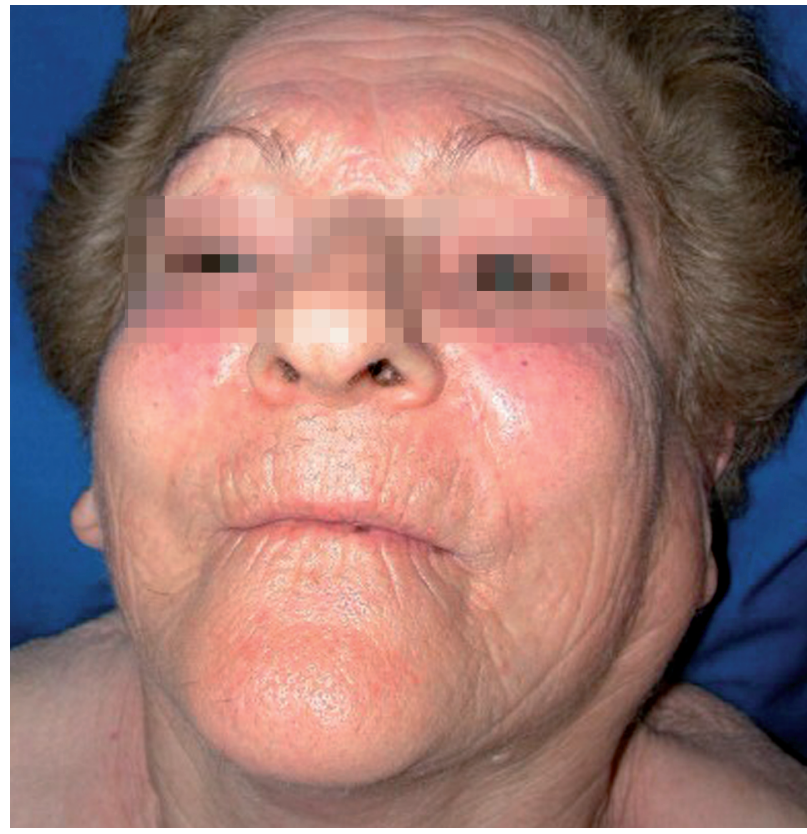

Figura 1. Imagen preoperatoria. Nótese la asimetría facial. Figure 1. Preoperative view. Note facial asymmetry.

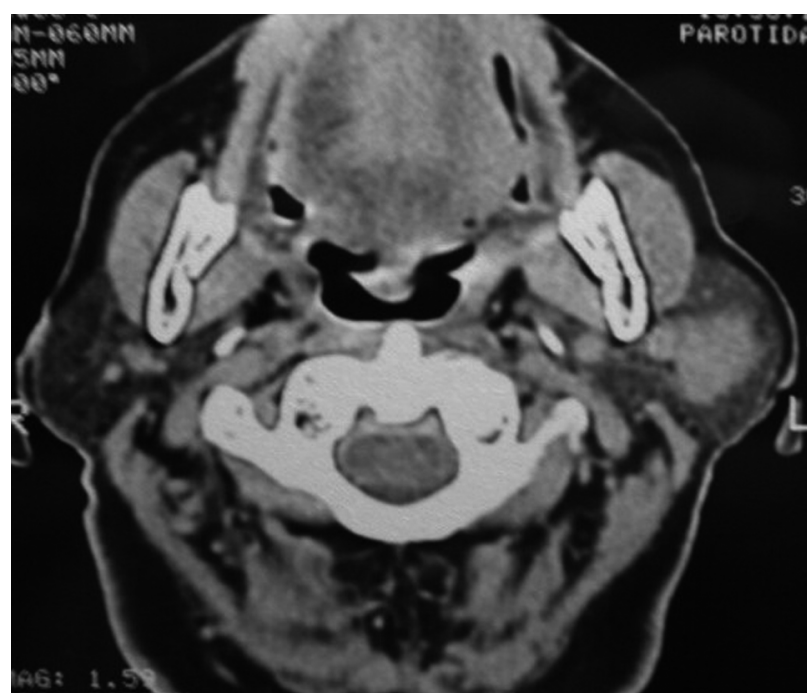

Figura 2. Corte tomográfico axial donde se observa la formación tumoral.

Figure 2. Tomographic axial slice showing tumor formation.
Malignant myoepithelioma should be resected with wide security margins, and radiotherapy should follow. ${ }^{3}$

With regard to epi-myoepithelial carcinoma, the treatment of choice is resection of the tumor with wide margins. Various authors advise radiotherapy in those tumors with a diameter that is greater than $4 \mathrm{~cm}$ although it has been shown to have little radiosensitivity. ${ }^{4}$

\section{Case report}

Female patient, 67 years of age, was referred to the department of Maxillofacial Surgery of our hospital with a concentrated mass in the left parotid region. It had on palpation a pasty consistency, that was readily movable, and there were no signs of infection or disturbance to the skin. No adenopathy was felt in the neck lymph nodes. There was no pain of any type in the area of the tumor. During the intraoral examination no disturbance was observed. The time from onset was 3 years. The patient had no other systemic disturbance of relevance (Fig. 1).

A computed tomography was requested as a result of which it could be observed that the tumor was affecting the superficial lobe of the left parotid gland. There was no sign of any disturbance to neighboring tissue. Given the clinical signs, the presumed diagnosis was of benign tumor of the salivary glands (Fig. 2).

Under general anesthesia and using an extraoral approach, the tumor was removed and a superficial gland lobectomy of the parotid gland was carried out, and the facial nerve was preserved (Figs. 3 and 4).

The pathologic anatomy confirmed the diagnosis of benign myoepithelioma. The immunohistochemical analysis revealed typical markers for clear myoepithelial cells: actin, S-100 protein and vimentin ${ }^{8}$ (Figs. 7,8 and 9). 


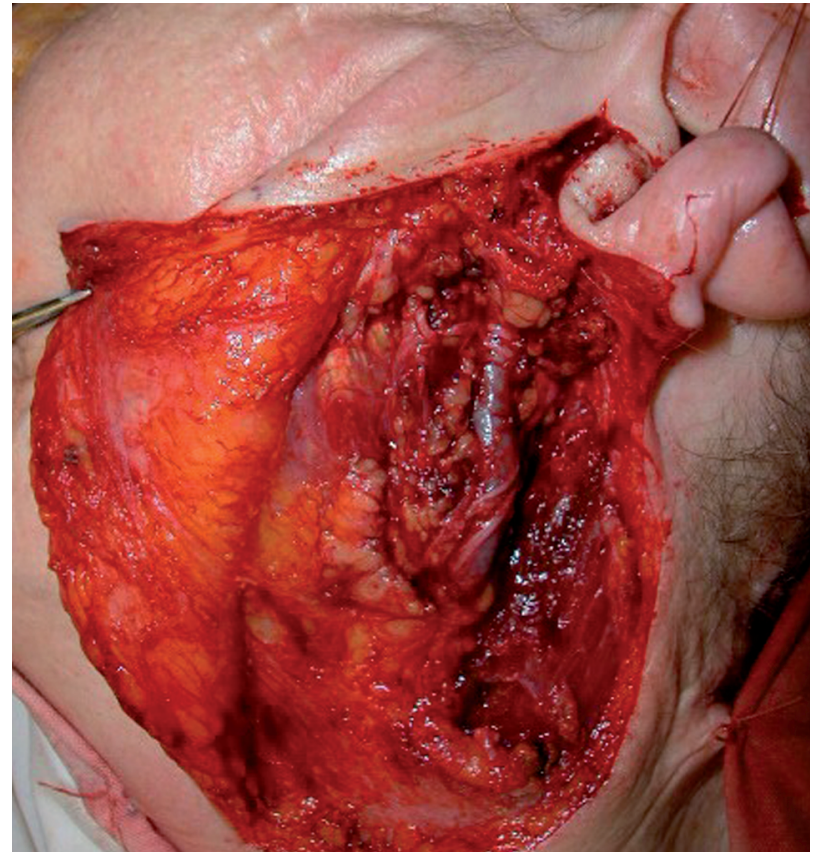

Figura 3. Imagen intraoperatoria mostrando la lobectomía superficial.

Figure 3. Intraoperative view showing superficial lobectomy.

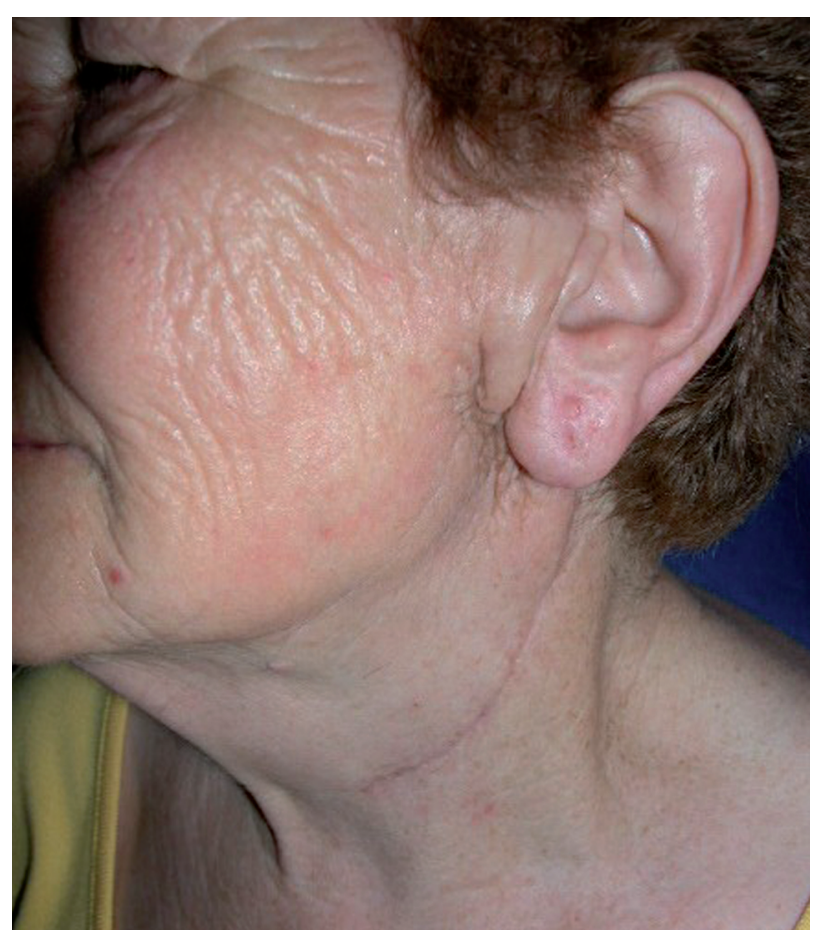

Figura 5. Postoperatorio (3 semanas).

Figure 5. Postoperative period (3 weeks).

dulas salivales ya que se presentan muchas similitudes en estas patologías, lo que con frecuencia deriva en un tratamiento incorrecto.

El cirujano debe prestar especial atención en el informe anatomopatológico, ya que un patólogo con poca experiencia en el

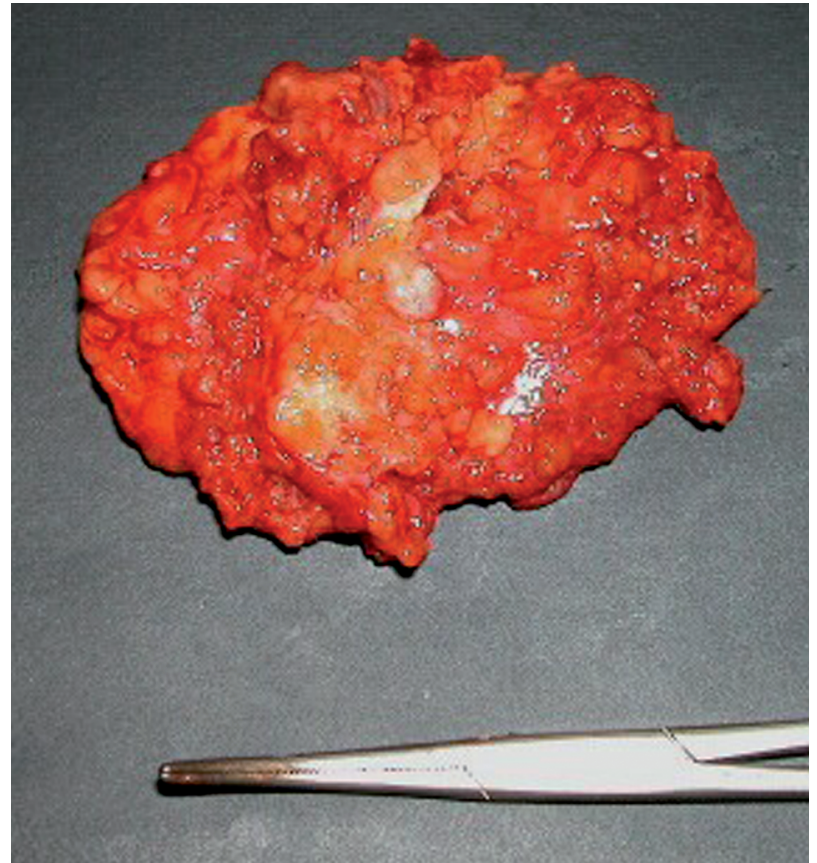

Figura 4. Macroscopía de la pieza quirúrgica. Figure 4. Macroscopical view of surgical specimen.

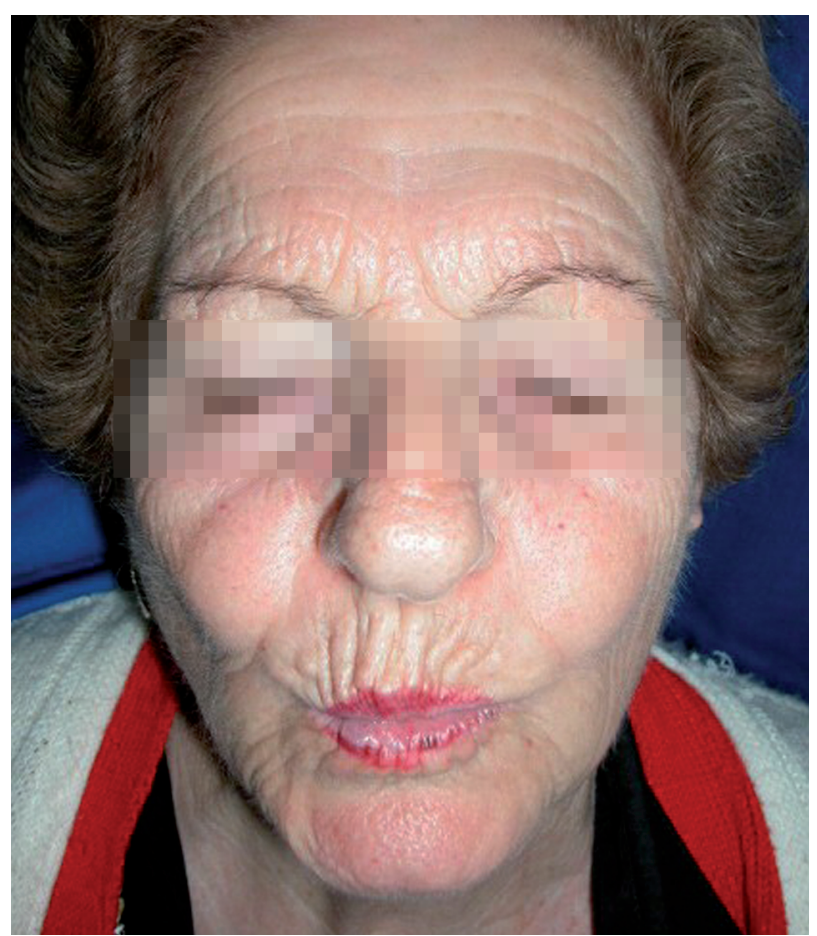

Figura 6. Postoperatorio (4 meses), con función muscular normal. Figure 6. Postoperative period (4 months), with normal muscular function.

There were no complications during the postoperative period. There was only paresis of the muscles around the operated side of the cheek, which remitted three months later. After a follow-up of a year there have been no signs of recurrence (Figure 5 and 6 ). 
área puede confundir un mioepitelioma benigno con un carcinoma epi-mioepitelial, o también con la variedad maligna del mioepitelioma. En tal caso se haría una cirugía conservadora, cuando lo correcto sería hacer una cirugía con amplios márgenes de seguridad. Debido a estos errores de diagnóstico, la recurrencia del carcinoma epi-mioepitelial es comparativamente alta (20 al $50 \%) .{ }^{5}$ Asimismo, el elevado índice de recurrencias de la variedad maligna del mioepitelioma, de hasta un $60 \%$, también puede deberse a errores de diagnóstico, los cuales originan cirugías inadecuadas para el caso.

Además se debe establecer un diagnóstico diferencial con otros tumores glandulares: adenoma pleomorfo, carcinoma adenoquístico, carcinoma mucoepidermoide, adenocarcinoma de células claras, adenocarcinoma de células acinares.

Por nuestra experiencia podemos decir que es importante realizar un tratamiento correcto en primera instancia. Si bien los mioepiteliomas benignos tienen buen pronóstico, existe evidencia de recurrencias con transformación maligna luego de resecciones incompletas, ya sea por transformación maligna de los restos de la patología primaria, o debido a regiones inicialmente malignas que no fueron incluidas en la resección. Por esta razón, siempre que sea posible, preferimos resecar a este tumor benigno con al menos un pequeño margen de seguridad si la localización lo permite.

\section{Agradecimientos}

Dr. Eduardo A. Mareso (Médico patólogo, Hosp. MLV, Moreno).

\section{Bibliografía}

1. Batsakis JG,EL-Naggar AK,Luna MA. Pathology consultation: Epithelial- myoepithelial carcinoma of salivary glands. Ann Otol Rhinol Laryngol 1992:101:540.

2. Gnepp Douglas R. Diagnostic Surgical Pathology of the Head and Neck. WB. Saunder Company 2001;357-60.

3. Gnepp Ellis Auclair. Surgical Pathology of the Salivary Glands. W.B. Saunder Company $1991 ; 182-4$.

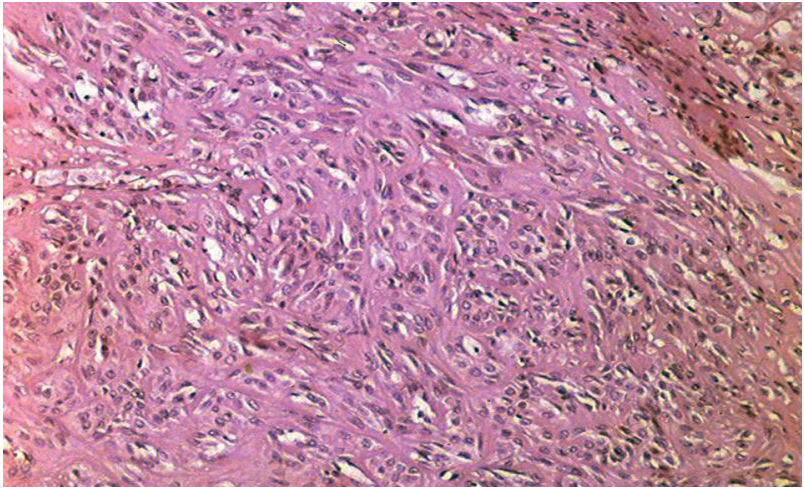

Figura 7. Se observan pequeños haces celulares separados por tractos fibrosos. HE (400x).

Figure 7. Small bundles of cells can be observed separated by fibrous tracts. HE (400x).

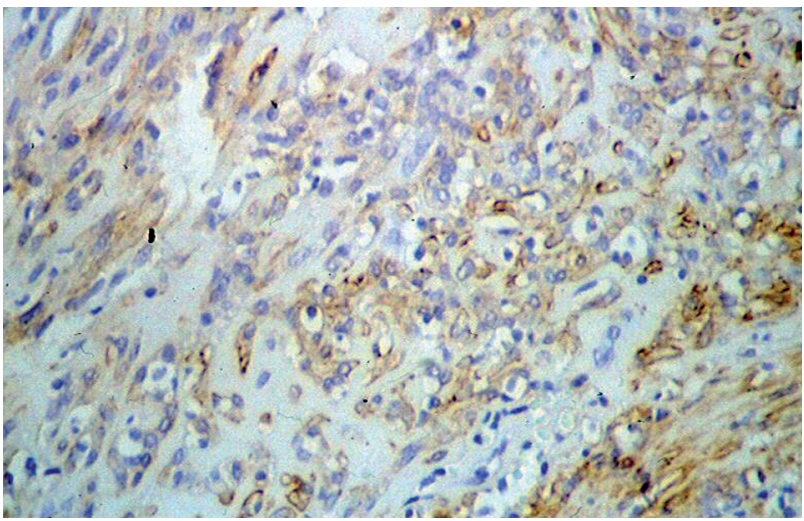

Figura 8. Se observa inmunoreactividad en células fusiformes y redondas con el anticuerpo contra actina muscular específica (400x). Figure 8. Immunoreactivity can be observed in spindle shaped and round cells with antibodies against muscle-specific actin. (400x).

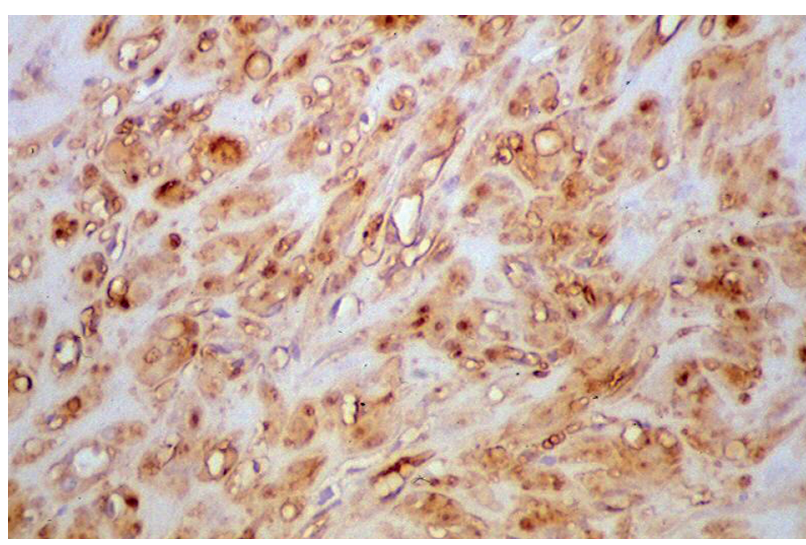

Figura 9. Se puede ver inmunoreactividad a la proteína S100 en células fusiformes y redondas (400x).

Figure 9. Immunoreactivity can be observed against 5100 protein in the spindle shaped and round cells. (400x).

\section{Discussion}

It is of great important that pathologists with a wide knowledge of salivary gland tumors carry out the diagnosis, as there are many similarities in these pathologies that frequently result in incorrect treatment.

The surgeon should give special attention to the anatomopathologic report as a pathologist with little experience in this area can confuse benign myoepithelioma with epi-myoepithelial carcinoma, or with the malignant variety of myoepithelioma. In this case conservative surgery should be carried out, when surgery involving wide safety margins would be correct. Given these diagnostic errors, the recurrence of epi-myoepithelial carcinoma is relatively high (20-50\%). ${ }^{5}$ Thus the high rate of recurrence of the malignant variety of myoepithelioma is as much as $60 \%$. This can be due to diagnostic errors that lead to inadequate surgery in each case.

In addition, a differential diagnosis should be established with other glandular tumors: pleomorphic adenoma, adenocystic carcinoma, mucoepidermoid carcinoma, clear cell adenocarcinoma, acinic cell adenocarcinoma.

Given our experience, we are able to state that carrying out correct treatment in the first instance is of great important. While there is good prognosis for benign myoepithelioma, there is evidence of recurrence and malignant transformation following incomplete resection, either because of the malignant transformation of the remaining 
4. Friedrich Reinhard E, Donath Karl. epithelial-myoepithelial carcinoma of the parotid gland with multiple distant metastases: A Case Report. J Oral Maxillofac Surg 2000;58:690-4.

5. Inoue Yuko, Nomura Jouji, Hashimoto Masanori, Tagawa Toshiro. Epithelialmyoepithelial carcinoma of the palate: a case report. J Oral Maxillofac Surg 2001; 59:1502-5.

6. Kaneko Hiroyuki, Muramatsu Takashi, Ogiuchi Hideki, Shimono Masaki. Epithelial-myoepithelial carcinoma arising in the submandibular gland: a case report with immunohistochemical study. J Oral Maxillofac Surg 2000;58:98-102.

7. Cho-KJ, el-Naggar AK, Ordonez NG, Luna MA, Austin J, Batsakis JG. Epithelialmyoepithelial carcinoma of salivary glands. A clinicopathologic, DNA flow cytometric, and immunohistochemical study of Ki-67 and HER-2/neu oncogene. Am J Clin Pathol 1995;103:432-7.

8. Alos L, Cardesa A, Bombi JA, Mallofre C, Cuchi A, Traserra J. Myoepithelial tumors of salivary glands: a clinicopathologic, immunohistochemical, ultrastructural, and flow-cytometric study. Semin Diagn Pathol 1996;13:138-47. primary pathology, or due to regions that were initially malignant that were not included in the resection. For this reason we prefer, whenever possible, to remove this benign tumor while leaving at least a small safely margin if its location permits this.

\section{Aknowledgments}

Dr. Eduardo A. Mareso (Doctor of Pathology, Hosp. MLV, Moreno). 